\title{
Share your expertise at ACRL's 6th national conference
}

\author{
By Joseph A. Boissé \\ Chair, ACRL National Conference Executive Committee
}

\section{Answer this call for participation}

\section{$\mathbf{T}$} he National Conference Fxecutive Committee invites you to participate in the ACRL Sixth National Conference to be held in Salt Lake City, Utah, April 12-14, 1992. The conference theme, "Academic Libraries: Achieving Excellence in Higher Education," will explore the major issues confronting academic libraries at the end of the twentieth century. The following are the sub-themes of the conference:

-diversity in the academic community;

the increased complexity of information resources in many formats;

the research agenda for academic and research libraries;

and technology and library users.

The Committee needs your proposal for papers, programs, and poster sessions. Your contribution will help achieve the overall goals of national conferences: a) to contribute to the total professional development of academic and research librarians, and b) to promote study, research and publication relevant to academic and research librarianship.

\section{Contributed Papers}

Contributed papers are a major feature of ACRL conferences and are invited in the following two categories:

Research papers are descriptions of studies that use rigorous research methodology and include identified hypotheses and clearly stated conclusions. The maximum length for a manuscript is 2,500 words.
Position papers are presentations where problems are clearly identified and solutions proposed. Descriptions may be locally implemented experiences (successes and failures), theoretical models, or state of the art reviews. Although not requiring formal research methodologies, these papers should be well organized, and should develop clear positions or concepts. The maximum length for a manuscript is 1,800 words.

Each contributed paper will be reviewed by at least two referees in a blind reviewing process. Criteria for selection include clarity, originality, relevance to the theme, and timeliness of the topic.

Accepted papers will be returned to the authors for final editing and preparation of a final copy for the published conference proceedings. Authors will have fifteen to twenty minutes to present their papers, followed by ten to fifteen minutes for comments and reactions from the audience; a maximum of one half hour will be devoted to each paper. Authors must attend the conference at their own expense. Additional instructions to authors will be mailed upon receipt of a notice of intention to submit a paper.

Potential contributors should send a 200-word description of their paper, the tentative title, category (research or position), their name, mailing address, and work phone number. Deadline for sending a notice of intent to submit a paper is May 1,1991 . The deadline for submitting the full paper is July 31,1991 . Send the notice and full paper to Stella Bentley, ACRL Contributed Papers, Library 3589, University of California, Santa Barbara, CA 93117. 


\section{Program Sessions}

Programs sessions are panel discussions or presentations where participants address an issue of concern to academic or research librarians. These one- to two-hour sessions allow for multiple perspectives on the issue and often include active participation from the audience. The planned portion of the program might use presentation of formal papers, the debate format, questions to and answers from a panel, or other format appropriate to the goal of the session.

Selection of sessions will be based on the clarity of the issue, the appropriateness of the topic, the relevance to the conference themes, and the contribution of the topic to an overall balance in coverage of issues of interest to academic and research librarians attending the conference. Participants in a program session must attend the conference at their own expense.

\section{BI evaluations sought}

Librarians who have used evaluation forms in conjunction with their library instruction sessions are asked to share those forms with the Research Committee of ALA's Library Instruction Round Table. Forms may be sent to committee member Kathy Dahl at University Library, Western Illinois University, Macomb, IL 61455 ; (309) 298-2742 or -2700 . Forms received before the ALA annual conference in June will be of most value.

\section{Free folk music guide}

The American Folklife Center at the Library of Congress has released American Folk Music and Folklore Recordings 1989: A Selected List. The guide lists the best recordings of American folk music and folklore issued by various companies and organizations during the year, as selected by a panel of experts. Many of these recordings elude mainstream distribution networks and seldom appear in record shops and catalogs, but they have been instrumental in preserving America's heritage and encouraging performers in local communities. The record ings are also valuable resources for students, teachers, and librarians. The illustrated list of 35 recordings from 1989 is available free of charge from the American Folklife Center, Library of Congress, Washington, DC 20540.
Potential organizers of program sessions should submit the program proposal form (call the ACRL office, (800) 545-2433, ext. 2516 for the form). The deadline for submitting the completed form is July 31, 1991. Send the completed form to Mary Ellen Elsbernd, Collection Development Librarian, ACRL Program Proposals, Northern Kentucky University, Steely Library, Highland Heights, KY 41076.

Program sessions may or may not be included in the conference proceedings at the participants' discretion. To be included in the conference proceedings, the manuscripts from the session, which may be papers presented and/or a summary of the session discussion, must be in the hands of the person named above by June 1, 1992.

\section{Poster Sessions}

Poster sessions are informal presentations of unique and trend setting programs and activities being carried out in academic or research libraries. A poster session consist of a series of concurrent graphic presentations in the form of photographs, tables, charts and other visual representation of information about the program or activity. The visuals should provide sufficient information that on their own could convey the story of the activity or program. The presenter must be available to answer questions and discuss the information with attendees.

Proposals for poster sessions will be judged for the relevance to the conference theme, the value of the activity or program presented to the academic or research library community, the uniqueness of the idea and the clarity with which it is presented. Poster session presentations will not be included in the Conference Proceedings, but a compilation of the abstracts will be available at the conference. Contributors of poster sessions must attend the conference at their own expense.

Potential presenters of poster sessions should submit a poster sessions proposal form (call the ACRL office, (800) 545-2433, ext. 2516 for the form). The deadline for submitting a completed form is November 1, 1991. Send the completed form to Jean E. DeLauche, ACRL Poster Sessions, 7040 North 60 th Street, \#203, Milwaukee, WI 53223.

$E d$. note: Serving on the National Conference Executive Committee are: Joseph A. Boissé, University of California, Santa Barbara; Stella Bentley, University of California, Santa Barbara; Sherrie S. Bergman, Wheaton College; Clarence E. Chisholm, Pennsylvania State University; Jean E. DeLauche, Alverno College; Mary Ellen Elsbernd, Northern Kentucky University; Tom Kirk, Berea College; and Mara Pinckard, Arizona State University. 